\title{
Commentary: Greek Yogurt and 12 Weeks of Exercise Training on Strength, Muscle Thickness and Body Composition in Lean, Untrained, University-Aged Males
}

\author{
Johan Jakobsson* \\ Sports Medicine Unit, Community Medicine and Rehabilitation, Umeå University, Umeå, Sweden
}

Keywords: greek yogurt, resistance training, strength training, exercise, protein intake

\section{A Commentary on}

Greek Yogurt and 12 Weeks of Exercise Training on Strength, Muscle Thickness and Body Composition in Lean, Untrained, University-Aged Males

OPEN ACCESS

Edited by:

Andrew Philp,

Garvan Institute of Medical

Research, Australia

Reviewed by:

Nicholas A. Burd,

University of llinois at

Urbana-Champaign, United States

Gareth A. Wallis,

University of Birmingham,

United Kingdom

*Correspondence:

Johan Jakobsson

johan.jakobsson@umu.se

Specialty section:

This article was submitted to

Sport and Exercise Nutrition,

a section of the journal

Frontiers in Nutrition

Received: 30 May 2019

Accepted: 13 August 2019

Published: 10 September 2019

Citation:

Jakobsson J (2019) Commentary:

Greek Yogurt and 12 Weeks of Exercise Training on Strength, Muscle

Thickness and Body Composition in

Lean, Untrained, University-Aged

Males. Front. Nutr. 6:137.

doi: 10.3389/fnut.2019.00137 by Bridge, A., Brown, J., Snider, H., Nasato, M., Ward, W. E., Roy, B. D., et al. (2019). Front. Nutr. 6:55. doi: 10.3389/fnut.2019.00055

\section{INTRODUCTION}

With great interest, I read the article by Bridge et al. (1). Following a discussion on resistance training and dairy protein, the authors studied the effect of Greek Yogurt (GY) consumption in combination with 12 weeks of resistance training on strength, muscle thickness and body composition in lean, untrained, university-aged males. This commentary intends to constructively comment on the recently published article by Bridge et al. by discussing some of the results, conclusions, and the study design.

The authors are discussing the potential of GY as a viable post-exercise food, due to its high protein content. The protein in GY is mostly casein, which is discussed as a protein with unique characteristics because it can prolong plasma amino acids and enhance whole-body protein turnover due to its slow absorption (2) and thus, allowing a net positive protein balance over a prolonged period of time (3). Given the effectiveness of milk in the context of stimulating muscle protein synthesis (MPS) $(4,5)$ and health-related benefits of yogurt consumption $(6-9)$ it is discussed that further studies on GY are warranted.

\section{DISCUSSION}

One aim of the paper was to assess if GY could be used as a whole food source of protein to support training adaptations vs. an iso-energetic control. The authors accurately acknowledge this question but become quite speculative on the beneficial effects of GY. In the introduction, the authors raised an interesting question: Would other dairy products elicit the same positive adaptations to resistance training as milk? However, this study compared GY to a carbohydratebased pudding with no protein. One group consumed $200 \mathrm{~g}$ of GY (110 kcal, $20 \mathrm{~g}$ protein, $8 \mathrm{~g}$ carbohydrates) 3 times/day on training days, and $150 \mathrm{~g}$ of GY 2 times/day on non-training days. The control group consumed an iso-energetic, semi-solid carbohydrate-based chocolate-flavored placebo pudding (110 kcal, 0 g protein, 28 g carbohydrates). 
Because the GY group received an additional $60 \mathrm{~g}$ of protein on training days, and $40 \mathrm{~g}$ on non-training days, their protein consumption $(1.74 \mathrm{~g} / \mathrm{kg} / \mathrm{d})$ was significantly higher than the control group's $(1.22 \mathrm{~g} / \mathrm{kg} / \mathrm{d})$. It is evident that an increase in protein consumption of this magnitude will increase the adaptations and muscle hypertrophy by resistance training, as shown by several studies (10-14) and extensive meta-analyses (15-17). Participants in the GY group also consumed GY before bed, which most likely resulted in a decrease in muscle protein breakdown overnight (10).

Thus, the results are expected and leaves us with the question of whether other dairy products could elicit the same positive adaptations to resistance training as milk. While the study had several strengths, such as minimal inter-tester variation, and blinded trainers, as a result of the study design, it can only be concluded that a higher protein consumption, induced by $40-$ $60 \mathrm{~g}$ of protein derived from GY per day, will increase the strength and muscle thickness in untrained males in combination with resistance training during 12 weeks. Thus, high-protein bacteria fermented milk, in addition to whole-milk and milk protein concentrates such as whey, is able to potentiate adaptations from resistance training.

The study contributes to the literature of GY and protein supplementation and GY could be considered as a viable postexercise food. However, while not the primary aim of the study, it would have been of great value to include a group consuming just milk, or whey protein, to answer the question regarding the effectiveness of other dairies in addition to milk.

\section{REFERENCES}

1. Bridge A, Brown J, Snider H, Nasato M, Ward WE, Roy BD, et al. Greek yogurt and 12 weeks of exercise training on strength, muscle thickness and body composition in lean, untrained, university-aged males. Front Nutr. (2019) 6:55. doi: 10.3389/fnut.2019.00055

2. Boirie $\mathrm{Y}$, Dangin M, Gachon P, Vasson MP, Maubois JL, Beaufrere B. Slow and fast dietary proteins differently modulate postprandial protein accretion. Proc Natl Acad Sci USA. (1997) 94:14930-5. doi: 10.1073/pnas.94.26. 14930

3. Reitelseder S, Agergaard J, Doessing S, Helmark IC, Lund P, Kristensen $\mathrm{NB}$, et al. Whey and casein labeled with 1-[1-13C]leucine and muscle protein synthesis: effect of resistance exercise and protein ingestion. Am J Physiol Endocrinol Metabol. (2011) 300:E231-42. doi: 10.1152/ajpendo.005 13.2010

4. Josse AR, Tang JE, Tarnopolsky MA, Phillips SM. Body composition and strength changes in women with milk and resistance exercise. Med Sci Sports Exerc. (2010) 42:1122-30. doi: 10.1249/MSS.0b013e3181c $854 \mathrm{f6}$

5. Hartman JW, Tang JE, Wilkinson SB, Tarnopolsky MA, Lawrence RL, Fullerton AV, et al. Consumption of fat-free fluid milk after resistance exercise promotes greater lean mass accretion than does consumption of soy or carbohydrate in young, novice, male weightlifters. Am J Clin Nutr. (2007) 86:373-81. doi: 10.1093/ajcn/86.2.373

6. Dehghan $M$, Mente A, Rangarajan S, Sheridan P, Mohan V, Iqbal $R$, et al. Association of dairy intake with cardiovascular disease and mortality in 21 countries from five continents (PURE): a prospective cohort study. Lancet. (2018) 392:2288-97. doi: 10.1016/S0140-6736(18) 31812-9

7. Fisberg M, Machado R. History of yogurt and current patterns of consumption. Nutr Rev. (2015) 73(Suppl. 1):4-7. doi: 10.1093/nutrit/nuv020
With equivalent protein intake across groups, a comparison of different protein sources is enabled. Thus, reducing the effects of a discrepancy in daily protein intake which will alter the adaptation to resistance training (16). The well-read authors briefly mention these matters and compare the present study with similar chronic training studies. One could interpret the findings and improved adaptations as similar to what have been seen in prior studies with milk or whey supplementation, but this is only speculative. Thus, the limitations of the study remain, and the authors make some unsubstantiated claims on the beneficial effects of GY, such as GY could be more beneficial at promoting a positive protein balance than milk.

Nevertheless, the authors state an interesting question. Therefore, further studies analyzing consumption of GY, including measurements of plasma amino acid concentrations and measurements of muscle protein synthesis, briefly mentioned by the authors, are of interest to further shed light in the context of GY consumption in combination with resistance training. By using stable isotope methods, researchers could decipher the anabolic potency of GY on the stimulation of MPS enabling more in-depth comparison of GY vs. other protein sources, and the potential of a whole-foods matrix on positively influencing the utilization of amino acids by muscle tissue (18).

\section{AUTHOR CONTRIBUTIONS}

JJ conceived, wrote, and revised the manuscript.

8. Wu L, Sun D. Consumption of yogurt and the incident risk of cardiovascular disease: a meta-analysis of nine cohort studies. Nutrients. (2017) 9: E315. doi: 10.3390/nu9030315

9. Thorning TK, Bertram HC, Bonjour JP, de Groot L, Dupont D, Feeney E, et al. Whole dairy matrix or single nutrients in assessment of health effects: current evidence and knowledge gaps. Am J Clin Nutr. (2017) 105:1033-45. doi: 10.3945/ajen.116.151548

10. Snijders T, Trommelen J, Kouw IWK, Holwerda AM, Verdijk LB, van Loon LJC. The impact of pre-sleep protein ingestion on the skeletal muscle adaptive response to exercise in humans: an update. Front Nutr. (2019) 6:17. doi: $10.3389 /$ fnut.2019.00017

11. Trommelen J, van Loon LJ. Pre-sleep protein ingestion to improve the skeletal muscle adaptive response to exercise training. Nutrients. (2016) 8:E763. doi: $10.3390 /$ nu 8120763

12. Phillips SM, Hartman JW, Wilkinson SB. Dietary protein to support anabolism with resistance exercise in young men. J Am Coll Nutr. (2005) 24:134-9s. doi: 10.1080/07315724.2005.10719454

13. Phillips SM, Tang JE, Moore DR. The role of milk- and soy-based protein in support of muscle protein synthesis and muscle protein accretion in young and elderly persons. J Am Coll Nutr. (2009) 28:343-54. doi: 10.1080/07315724.2009.10718096

14. Stokes T, Hector AJ, Morton RW, McGlory C, Phillips SM. Recent perspectives regarding the role of dietary protein for the promotion of muscle hypertrophy with resistance exercise training. Nutrients. (2018) 10:E180. doi: $10.3390 /$ nu 10020180

15. Cermak NM, Res PT, de Groot LC, Saris WH, van Loon LJ. Protein supplementation augments the adaptive response of skeletal muscle to resistance-type exercise training: a meta-analysis. Am J Clin Nutr. (2012) 96:1454-64. doi: 10.3945/ajcn.112.037556

16. Morton RW, Murphy KT, McKellar SR, Schoenfeld BJ, Henselmans M, Helms $\mathrm{E}$, et al. A systematic review, meta-analysis and meta-regression of the effect 
of protein supplementation on resistance training-induced gains in muscle mass and strength in healthy adults. Br J Sports Med. (2018) 52:376-84. doi: 10.1136/bjsports-2017-097608

17. Miller PE, Alexander DD, Perez V. Effects of whey protein and resistance exercise on body composition: a meta-analysis of randomized controlled trials. J Am Coll Nutr. (2014) 33:163-75. doi: 10.1080/07315724.2013.875365

18. Soop M, Nehra V, Henderson GC, Boirie Y, Ford GC, Nair KS. Coingestion of whey protein and casein in a mixed meal: demonstration of a more sustained anabolic effect of casein. Am J Physiol Endocrinol Metab. (2012) 303:E152-62. doi: 10.1152/ajpendo.00106.2012
Conflict of Interest Statement: The author declares that the research was conducted in the absence of any commercial or financial relationships that could be construed as a potential conflict of interest.

Copyright (๑) 2019 Jakobsson. This is an open-access article distributed under the terms of the Creative Commons Attribution License (CC BY). The use, distribution or reproduction in other forums is permitted, provided the original author $(s)$ and the copyright owner(s) are credited and that the original publication in this journal is cited, in accordance with accepted academic practice. No use, distribution or reproduction is permitted which does not comply with these terms. 